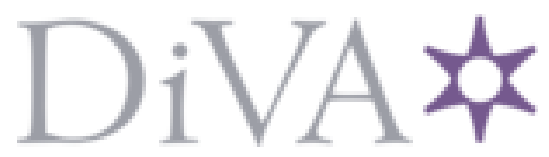

http://www.diva-portal.org

\title{
Preprint
}

This is the submitted version of a paper published in Energy Policy.

Citation for the original published paper (version of record):

Pacini, H., Assunção, L., van Dam, J., Toneto Jr, R. (2013)

The price for biofuels sustainability.

Energy Policy, 59: 898-903

http://dx.doi.org/10.1016/j.enpol.2013.03.042

Access to the published version may require subscription.

N.B. When citing this work, cite the original published paper.

Permanent link to this version:

http://urn.kb.se/resolve?urn=urn:nbn:se:kth:diva-143905 
Henrique Pacini ${ }^{\text {abl }}$

\section{The price for biofuels sustainability}

Lucas Assunção

Jinke van Dam ${ }^{\mathrm{c}}$

Rudinei Toneto Jr. ${ }^{\mathrm{d}}$

${ }^{a}$ Royal Institute of Technology, Sweden. ${ }^{b}$ United Nations Conference on Trade and Development (UNCTAD), Switzerland; ${ }^{c}$ Jinke van Dam Consultancy, The Netherlands; FEARP-USP, Brazil. ${ }^{\mathrm{d}}$ FEARP-USP, Brazil.

\section{Abstract}

The production and usage of biofuels has increased worldwide, seeking goals of energy security, low-carbon energy and rural development. As biofuels trade increased, the European Union introduced sustainability regulations in an attempt to reduce the risks associated with biofuels. Producers were then confronted with costs of sustainability certification, in order to access the EU market. Hopes were that sustainably-produced biofuels would be rewarded with higher prices in the EU. Based on a review of recent literature, interviews with traders and price data from Platts, this paper explores whether sustainability premiums emerged and if they represented an attracting feature in the market for sustainable biofuels. This article finds that premiums for ethanol and biodiesel evolved differently between 2011 and 2012, but have been in general very small or inexistent, with certified fuels becoming the new norm in the market. For different reasons, there has been an apparent convergence between biofuel policies in the EU and US. As market operators perceive a long-term trend for full certification in the biofuels market, producers in developing countries are likely to face additional challenges in terms of finance and capacity to cope with the sustainability requirements.

\footnotetext{
${ }^{1}$ Corresponding author. Contact: UNCTAD, Trade and Environment Branch, Office E8006. Tel/Fax +4122917 4693. E-mail: Henrique.pacini@unctad.org
} 
Keywords

Biofuels, Sustainability, Premiums, European Union, Development, Certification

\section{Introduction}

Many countries have investigated, deployed or are considering introducing biofuels in their national energy systems. This is partly due to climate change and the limited availability of cost-efficient options to reduce fossil fuel dependency in the transport sector. This is also based on the hope that the production and usage of biofuels can unlock new employment opportunities, strengthen rural economies and reduce the gap in value-added trade and innovation between developing and developed countries

Over the last decade, production and usage of biofuels went far beyond the borders of traditional biofuel-producing countries such as Brazil. Regulatory agents, companies and NGOs worldwide have followed the internationalization of this market, starting discussions on how to make biofuels production and consumption more responsive to environmental, social and trade concerns (UNCTAD, 2008a; UNCTAD, 2009; Börjesson, 2009, Van Dam et. al., 2010). While in some cases the number of jobs created and the amount of foreign energy displaced were not as large as estimated, emission performances of biofuels were nevertheless estimated to be positive (Rathmann et al, 2012). The expansion of biofuels was followed by discussion on risks such as food vs. fuel dilemmas, potential for land-grabs and deforestation. In addition to that, worries over the indirect impacts of biofuels expansion prompted a large body of literature on indirect land use changes (iLUC) effects of biofuels, specially over performances on lifecycle emissions when biofuels are compared to their fossil equivalents (Rosillo-Calle, 2011; Batista, 2012; Pimentel, 2005). Facing this scenario, policy-makers have introduced different regulations aimed at improving the "sustainability" of biofuels (Pacini and Strapasson, 2012; EC, 2009; EPA, 2010; 
CARB, 2009), whilst trying at the same time not to jeopardize the price-attractiveness of ethanol and biodiesel. Sustainability regulations adopted mechanisms to stimulate the uptake of advanced technologies which could increase supply and make biofuels more economically viable. At the same time, regulations sought to safeguard against risks by broadening the eligible feedstock base and lowering competition with food crops (UNCTAD, 2008b).

In the past, numerous environmental regulations targeted the biofuels industry at the national level (Kutas et al, 2007; Pacini and Strapasson, 2012). With the emergence of an international market for biofuels in the post-2005 period, it became important to consider supranational initiatives to guide sustainability in this market. Even though the importance and appropriateness of sustainability regulations was unquestioned, their formulation and scope was, and still remains, far from consensual among private, public and civil society stakeholders (Van Dam et. al., 2010; Schlegel, 2007).

Amid fears of market fragmentation due to different standards, a regulatory baseline was partially achieved in 2009 when the European Union adopted a directive containing sustainability provisions for biofuels (Afionis and Stringer, 2012; EC, 2009). ${ }^{2}$ For compliance, market agents were required to obtain certification from either voluntary schemes recognized by the Commission, through national schemes in EU memberstates or directly via bilateral or multilateral agreements with the EU (Pacini and Assunção, 2011).

\footnotetext{
${ }^{2}$ The EU criteria called for domestic and foreign suppliers of biofuels to meet minimum lifecycle greenhouse gas (GHG) emission thresholds, introduced provisions to avoid biofuel production in highly biodiverse and forested areas, in addition to reporting instruments for food security, water usage and labor rights, especially in developing countries. These sustainability criteria became mandatory for EU countries so that they could count biofuels and other bioliquids towards a $10 \%$ renewable energy goal for their transport sectors by 2020 .
} 
With the introduction of sustainability requirements in 2009 , the biofuels industry has had to cope with new costs. These additional costs affect producers in both developed and developing countries. There were hopes, however, that biofuels certified as sustainable would earn producers price premiums in European markets, working as an incentive to improve the industry, as well as grant an opportunity for developing country producers to uptake sustainable production and engage in profitable exports of clean fuels to Europe.

This article explores the opportunity costs of biofuels certified as sustainable in relation to non-certified biofuels. The economic success of biofuels in general (certified and non-certified) in relation to fossil fuels is largely determined by other external drivers such as the fossil fuel price and feedstock commodity prices. Based on recent price data and twenty interviews with experts, producers and biofuel traders worldwide, this article discusses the issue of costs for producers to adapt to the EU sustainability requirements, as well as the absence of strong price premiums for certified biofuels, which were once seen as a potential attracting feature to this market. Conclusions are then summarized in the last session.

\section{The opportunities and costs of sustainable biofuels}

The internationalization of biofuels markets was driven by the trade relationship between the United States, the European Union and Brazil, which share similar goals of promoting green jobs, de-carbonize their transport sectors, as well as reducing their respective reliances on oil. The commoditization of biofuels was driven by blending mandates and relative production efficiencies, which resulted on price spreads appearing between different markets (UNCTAD, 2009). Producers then engaged in 
trade opportunities, which allowed the attainment of higher prices in foreign markets, sometimes delivering higher returns than what was possible in domestic markets alone. Biofuel production costs have experienced a steep decline since the large-scale biofuel programs started in the late 1970s. Studies pointed at learning curve effects bringing down ethanol production costs in Brazil (Goldenberg et al, 2004), in the US (Hettinga et al, 2009) and at a global level (de Wit et al, 2010). According to Hettinga et al (2009), higher ethanol yields, lower energy use and the replacement of beverage alcohol-based production technologies have mostly contributed to substantial cost decline in the US. Crago et al (2010) found that while the cost of sugar cane ethanol production in Brazil is lower than that of corn ethanol in the US the inclusion of transportation costs for the former and co-product credits for the latter changes their relative competitiveness. As a matter of fact, while Brazil is endowed with large agricultural assets, its high domestic demand for ethanol coupled with the slow increase in production has led to the US overtaking Brazil as the major world exporter since 2011 (Pacini and Strapasson, 2012).

Figure 1 serves as an illustration of price premiums for anhydrous ethanol obtained by Brazilian exporters in the US and EU markets, when compared to domestic prices in Brazil. ${ }^{3}$

\footnotetext{
${ }^{3}$ It is worth noticing that the US has become the world's largest ethanol producer and exporter as of 2013.
} 


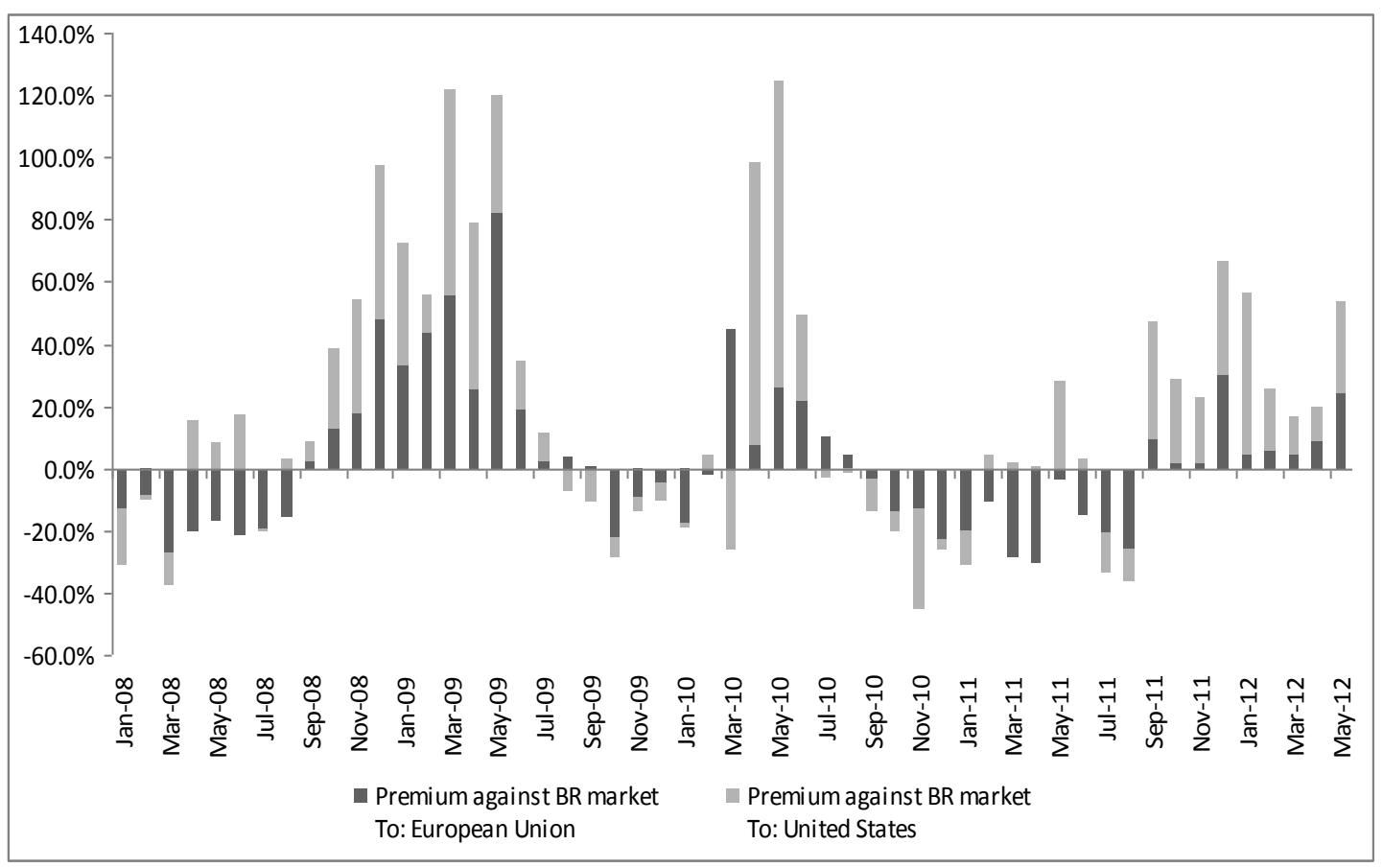

Figure 1. Price premiums for anhydrous ethanol obtained in selected export destinations (US and EU), compared to domestic prices in Brazil, 01.2008 to 05.2012. Prices adjusted to CIF, including freight and insurance to Rotterdam (EU) and Gulf (US).

Sources: Based on data from UNICADATA (2013) and CEPEA/Esalq (2013)

As of 2011 biofuel consumption in Europe amounted to 13.84 billion liters, an increase of $3.15 \%$ in energy terms compared to 2010 (EurObserv'ER, 2012). ${ }^{4}$ Major European biofuel users include Germany, France, Spain, Italy, UK, Poland and Sweden. The US on the other hand consumed more than 50 billion liters of ethanol in 2011, with just over 4 billion liters of biodiesel being utilized.

Figure 2 illustrates how price differentials presented in Fig. 1 resulted in trade flows between Brazil, the US and the EU. Taking into account freight and insurance costs, Brazilian ethanol exports obtained, in average, price premiums of $13.6 \%$ in the US and $2.8 \%$ in the EU between 2008 and 2012. This difference in spreads was reflected in the evolution of Brazilian exports, seen in Figure 2.

\footnotetext{
${ }^{4}$ There has been a decrease in the growth rate of biofuels consumption in Europe since 2008 due to the economic downturn, affecting exports from traditional producers such as Brazil, whose potential to export has been struggling with reduced credit lines and strong domestic demand (see Fig. 2).
} 


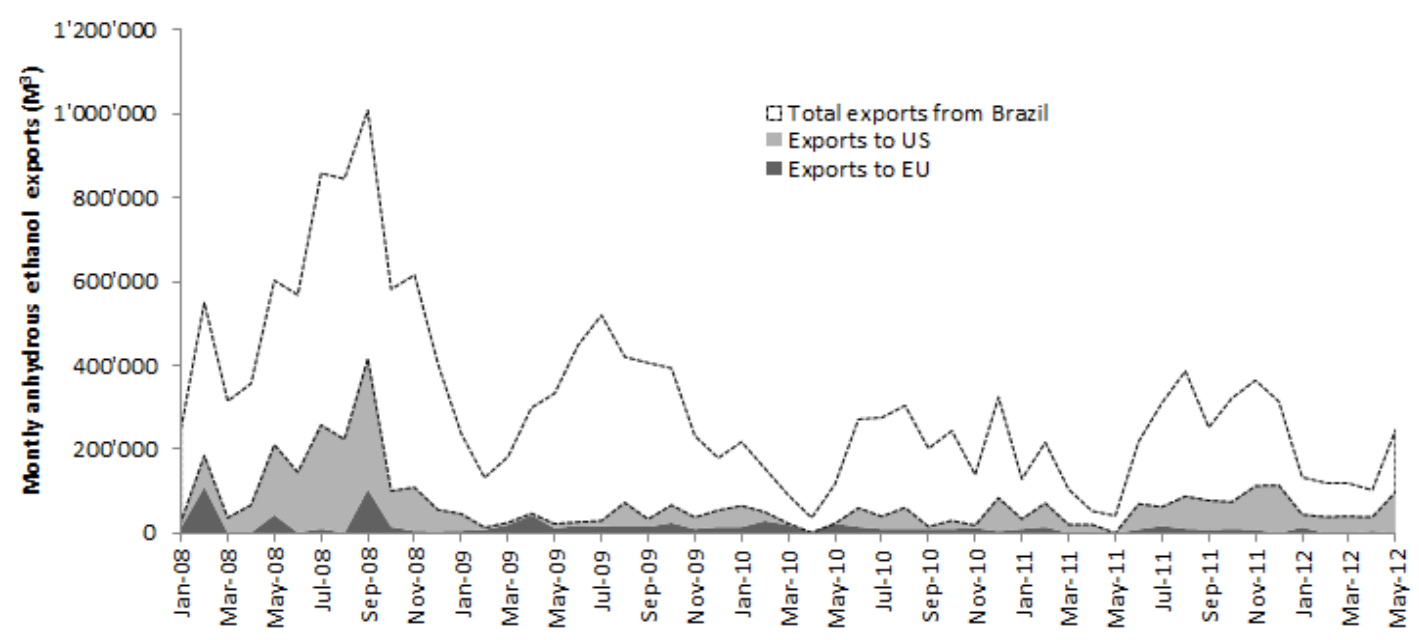

Figure 2. Exports of anhydrous ethanol from Brazil, 01.2008 to 05.2012. White area reflects indirect exports to the US via Caribbean countries (CBI initiative).

Sources: Based on data from UNICADATA and CEPEA/Esalq

Just as price premiums are crucial for producers seeking foreign markets, the expectation of sustainability premiums has become increasingly relevant (Mathews, 2008). Such premiums accrued by producers that engage in sustainability was expected to make certification attractive for producers. ${ }^{5}$ However, this turned out not to be always the case. Before an analysis of premiums can be made, let us understand the incentive mechanisms used to promote sustainable biofuels in the EU and US.

Since 2009, Europe committed to a $10 \%$ mandatory renewable energy goal for the transport sector by 2020 . Biofuels were - and still are - the strongest candidate to meet the bulk of this mandate (ECN, 2011). To reduce risks associated with their increased usage, biofuels counting towards the national mandates were limited to those certified as sustainable. At the same time, incentives were given to biofuels made from waste, residues and lignocellulosic feedstocks, as those would be considered as counting double for the 2020 targets. The end result was a harmonized

\footnotetext{
${ }^{5}$ Notice the magnitude of sustainability premiums are not necessarily related to the lifecycle GHG performance of a specific biofuel. While biofuels with low GHG emmissions are more likely to succeed in obtaining certification, premiums are binomial - they exist for certified biofuels based solely on the binomial factor of being certified or not. Premiums are therefore independent from crops or processes gave origin to the biofuel.
} 
system for biofuels in all $27 \mathrm{EU}$ member states. ${ }^{6}$ While non-certified biofuels can still be used, the EU biofuels policy from 2009 left little economic reason for their adoption. $^{7}$

The United States did not introduce broad sustainability criteria for liquid biofuels similar to the European case. Instead, the US established a two-band system of regular and "advanced" biofuels - measured by their GHG performance including indirect land use changes and conversion pathways (EPA, 2010). Advanced biofuels including sugarcane and cellulosic ethanol - received the incentive of a market reserve of 60 billion litres, about half of the US quantitative blending mandate of 136 billion liters of ethanol by 2022 (EPA, 2010). This market share allowed the emergence of sustainability premiums of about \$0.20 USD per liter, equivalent to $36 \%$ per liter when compared to conventional (corn) ethanol (BP, 2012). The limitation is that through this market reserve, the incentive system in the US does not attempt to directly regulate social and biodiversity-related aspects of biofuel production, doing so only indirectly by promoting advanced technologies which potentially have fewer negative externalities. While the US rules on renewable fuels affect the largest world market for biofuels, they fell short of building a broader set of sustainability criteria as Europe did.

As the sustainability criteria for biofuels is introduced in the EU, protectionism fears have been raised and the industry expressed worries about the costs of complying with

\footnotetext{
${ }^{6}$ European member states had differences in national systems and legislations put in place to transpose the EU Renewable Energy Directive into national laws. Nevertheless, the core contents remained compatible with the EU requirements.

${ }^{7}$ Biofuels are, in most cases, more costly to produce than their fossil equivalents, reducing their chances of being incorporated into the fuel pool in the absence of subsidies or consumption mandates. Additionally, it could be argued that there is little governmental interest in the usage of non-certified biofuels, since they cannot be counted towards the national goals for 2020 .
} 
the new requirements (UNCTAD, 2008a, Van Dam and Junginger, 2011). In contrast, the EU rules also provided hopes of attractive price-premiums for sustainablyproduced biofuels, which were seen as an opportunity by producers in developing countries. Under this logic, the lack of pre-existing production capacity in some developing countries could work in their favor, allowing developing countries to engage in production systems "borne-compatible" with the EU requirements at a lower cost when compared to traditional biofuel-producing countries, where extensive adaptations would be necessary. In this sense, sustainability requirements could have been favorable to market entrants to gain access to EU markets, ultimately serving as a development driver for impoverished rural areas in Latin America, Africa and Asia.

The sustainability rules for biofuels entered into force in December 2010, becoming applicable in the entire EU. Since then, data has emerged on the premiums that certified biofuels have obtained in the European market. The price data paints a different reality from when sustainability premiums were expected to drive a major change in markets, as well as bringing new producers into the scene. This will be explored in the next session.

\section{Higher costs, but no price-premiums}

In order to have their products certified as sustainable in the EU, biofuel producers both within and from outside the EU have to adjust to the requirements of the Renewable Energy Directive (RED), bringing changes to their cost structure. While selecting and implementing one of the voluntary schemes accredited by the European Commission (Pacini and Assunção, 2011; Van Dam et al., 2012), producers incur in a number of direct and indirect costs (CIFOR, 2012): 


\section{Direct costs}

- Certification fees: Costs levied by the certifying entity; the fee structure might be fixed or based on the quantity certified or various combinations. In some contractual modalities, controlling groups might pay for certification fees in exchange for locking suppliers into long-term contracts.

- Information costs: Costs related to gathering and analyzing data (e.g. biodiversity status of land, estimate of carbon stocks, maps).

- Changes to management systems: Costs related to the tracking of products, internal audits, quality control and integration of new data and analysis into production processes, including both those processes that remain unchanged and those that have been modified.

- Auditing fees: Costs incurred in monitoring visits and assessments by external agents (auditors) to guarantee neutrality.

\section{Indirect costs}

- Internal adaptation costs: Actions and costs associated with improved agricultural practices (e.g. lower impact tillage), more efficient equipment (e.g. engines or mills) and better controls (e.g. exhaust from industrial mills). These measures may also reduce production costs in the long run as resource usage becomes more efficient, so they could become benefits in the longer term. Producers surveyed mentioned that production units are chosen for certification according to their level of compatibility with the EU sustainability requirements. Those with the lowest estimated cost of certification are often the first to undergo the certification process.

It is difficult to estimate how those costs along the value chain impact biofuel prices in Europe, due to both business confidentiality and the fact that some of the 
adaptations necessary are undertaken towards multiple goals. ${ }^{8}$ Certification schemes which emerged to cater for the EU sustainability requirements on biofuels (Directive 2009/28/EC - EU-RED) have not been biofuel-only systems. Some schemes, such as Bonsucro, RTRS and RSB offer additional market facilities such as certification for sugar (required by large buyers such as Kraft foods and Coca-Cola in Brazil), certificate trading and cross-compliance with other certification systems such as the Rainforest Alliance (Bonsucro, 2011; RTRS, 2011; RSB, 2010). Traders surveyed declared that certification for sugar products is the main driver for producers in Brazil to seek compliance with the EU norms as of 2012 (exports to the EU have been of secondary importance, due to the large domestic biofuel demand in Brazil).

As it is not possible to obtain certification for "half a mill", operators tend to certify the low hanging fruits first: the newest mills or those requiring minor adaptations are often among the first selected for certification within a production group. One respondent from Sweden mentioned that, when seeking certification for biofuels produced from waste material, the largest costs were the large administration and documentation costs tied to the certification process.

During interviews with producers and traders, several respondents hinted that not all players in the production chain share the same cost burden. This appears to be a "push-the-bill-to-the-weakest" effect, where larger biofuel producers are likely to attempt to "outsource" certification costs as much as possible, by requiring smaller suppliers to adapt to the new requirements. For example, many biofuel mills are the de facto regional monopsonies for local business partners such as smaller-scale

\footnotetext{
${ }^{8}$ For example, adaptations can take place by standard technical progress, or to comply with national legislation.
} 
feedstock producers and service providers. Those might in turn be put into a disadvantaged position to relay rates to the mill operators. This could in some circumstances oblige smaller business partners to foot the bill for adaptations without being able pass along their costs to the buying group (CIFOR, 2012). Market concentration and bargaining power of market agents dealing with sustainability costs is an interesting field for further analysis.

Certification costs are difficult to estimate, since they are vary on a case-by-case basis. Yet, some estimations made by Van Dam et al (2012) place costs in ranges of 1$5 € /$ per ton of palm oil in Indonesia; $0.5-25 € /$ ton for jatropha in Tanzania; and $€ 0.5$ 4.5/ton of soy in Argentina. Unlike costs, there is much better availability of information concerning price-premiums between conventional and certified biofuels. Prices are different than costs: they also depend on the dynamics of supply and demand. Even if sustainability certification did not increase biofuel production costs (e.g. in the case where additional costs were cancelled by efficiencies of technical progress), supply and demand forces would still cause price-differences among certified vs. non-certified biofuels. To have a better perception of how sustainability premiums evolved in the markets, Figures 3 and $\mathbf{4}$ illustrate the price-premiums obtained by RED-compliant ethanol (from July 2011) and biodiesel (from February 2012) in European markets. ${ }^{9}$

\footnotetext{
${ }^{9}$ Considering any of the 11 schemes allowing market access in the EU: ISCC, Bonsucro EU, RTRS, RSB, 2BSvs, RBSA, Greenergy, Ensus, Red Tractor, SQC and Red Cert.
} 


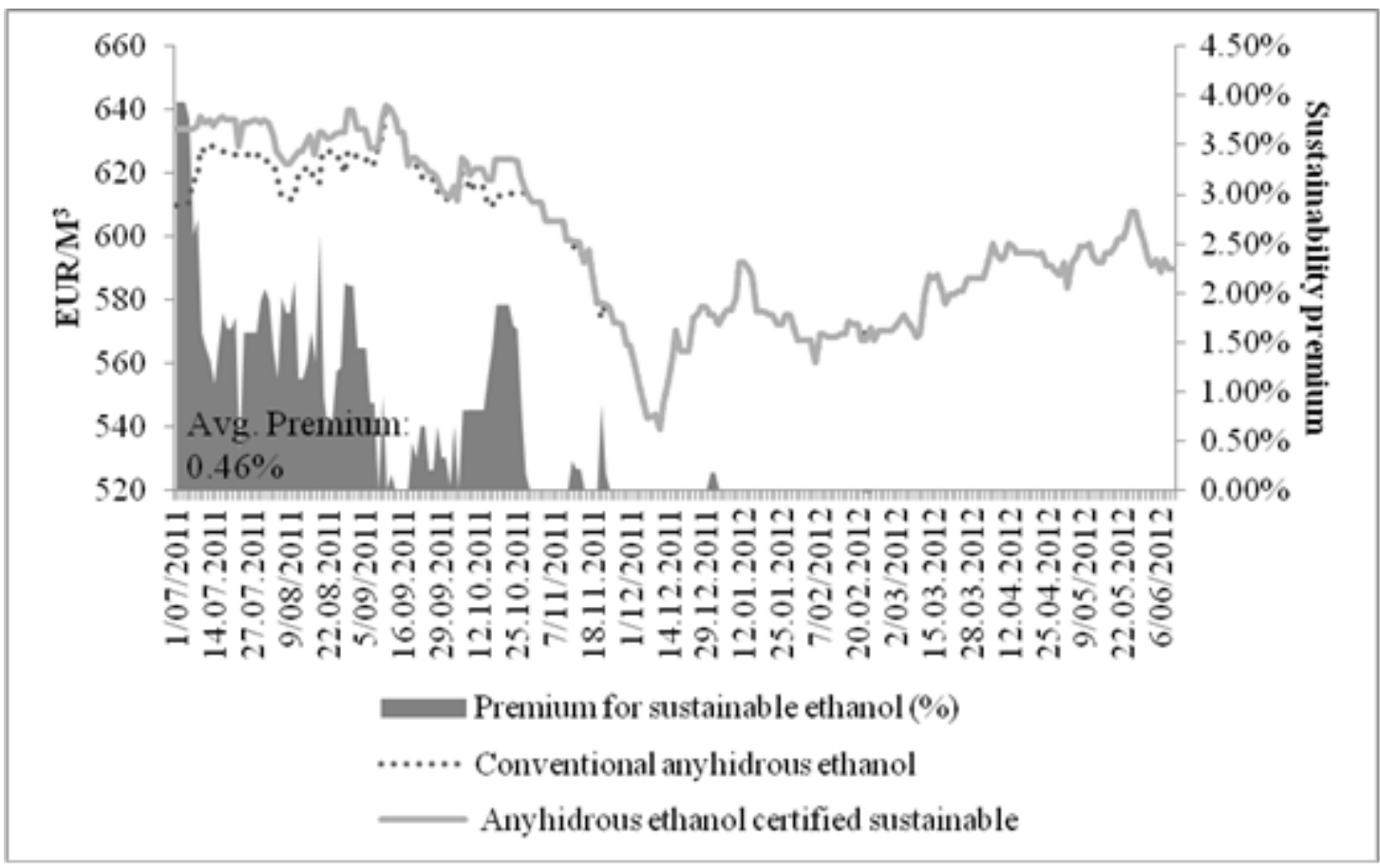

Figure 3. Prices of certified sustainable ethanol (anhydrous, EU-RED Compliant) vs. regular anhydrous ethanol. Prices per cubic meter (left axis) and magnitude of premiums (right axis).

Source: Adapted based data from Platts.

Certified ethanol had a short lived premium in European markets. The average premium for certified ethanol was only $0.46 \%$ over regular ethanol. The peak premium ammounted to $3.93 \%$ in the second semester of 2011, and since the end of that year there has been practically no premium for ethanol certified sustainable! In the words of a trader: "There is no market for non-certified product. You have to make it better but no one will pay anything extra for it". 


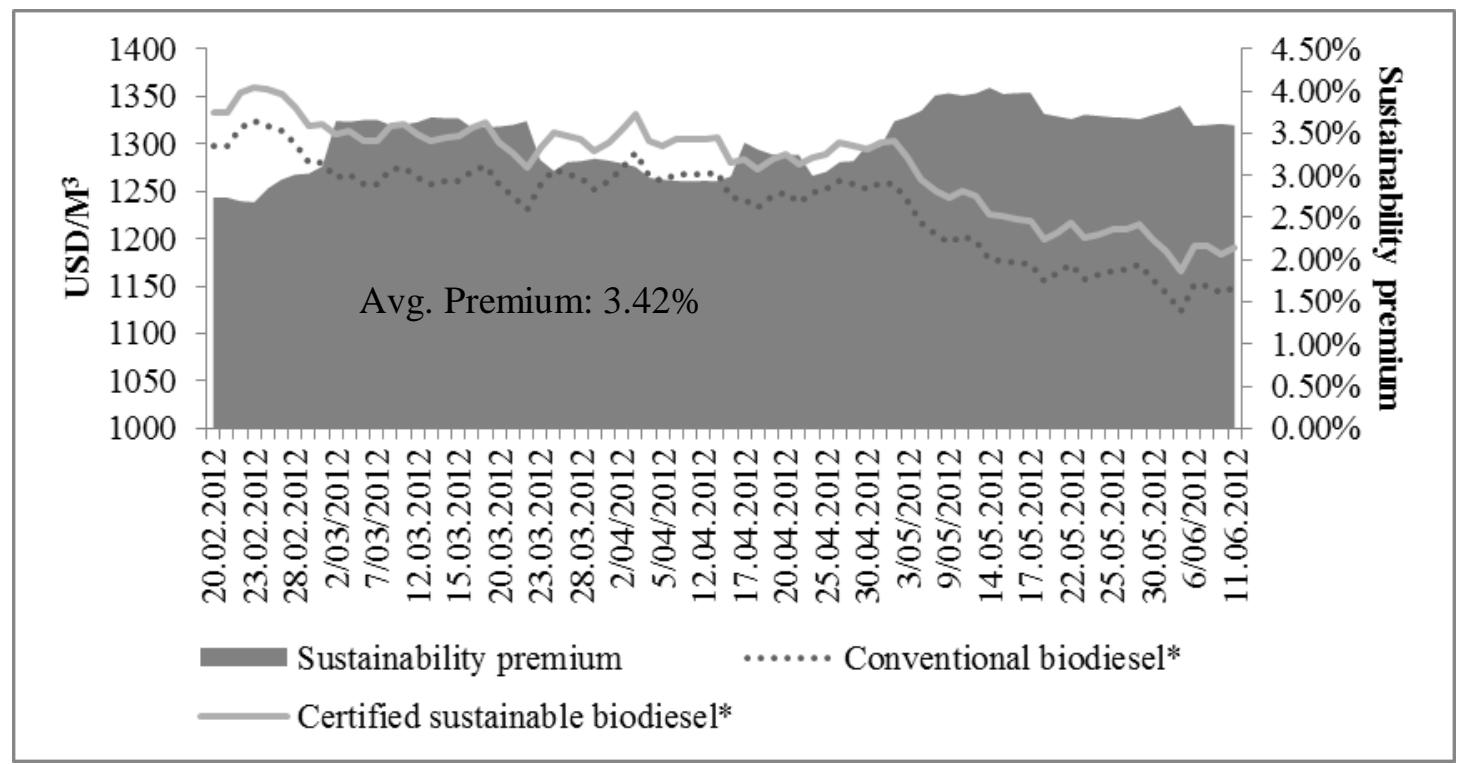

Figure 4. Prices of certified sustainable biodiesel (EU-RED Compliant) vs. regular biodiesel. Prices per cubic meter (left axis) and magnitude of premiums (right axis). * Prices considered as an average of SME, RME, FAME 0 and FAME - 10.

Source: Adapted based on data from Platts.

The EU biodiesel market is larger than the ethanol equivalent (respective consumptions of 12.8 and. 6.03 billion liters in 2011). Certified biodiesel trading in Europe between July 2011 and June 2012 displayed a near constant average premium of $3.42 \%$ (Maximum: $4.04 \%$ and Minimum: 2.68\%). While premiums in ethanol markets virtually disappeared in the end of 2011, biodiesel premiums have been relatively stable since data became available in February 2012. Still, according to traders interviewed for the elaboration of this study, the market expectation is for such premiums to disappear in line with what happened with ethanol, once enough supply levels become available to meet European demand for certified biodiesel.

The discussion on price premiums must be seen in light of the opportunity costs which market agents face while engaging in arbitrage between different markets (e.g. EU, US and Brazil) and sectors (food, feed and energy) (Cavalcanti et al, 2011). In markets where biofuel mandates are used (e.g. most of the European Union), the price of biofuel tends to be closely related to the price of the feedstock (de Gorter, 2009). On the other hand, in markets where the biofuel demand is constrained by blending limits, then demand for biofuels is likely to be determined by the price of oil (Serra et 
al., 2010). This second case figured clearly during the discussions on the ethanol blend wall in the United States (Zhang et al., 2010).

In both biofuel deployment strategies mentioned above (biofuel mandates and blending limits), sustainability premiums can arguably be determined by certification costs, available supply of certified volumes, as well as demand for certified fuel. Markets determine premiums for certified biofuels: in case supply falls, premiums increase. In case of oversupply, premiums decrease or they are not paid at all (Van Dam et al, 2012 p. 62). While the supply of certified ethanol has been in balance with demand since late 2011, the persistence of premiums for biodiesel could suggest that the supply and demand for certified biodiesel are not yet in equilibrium in Europe. The role of Germany (as a main consumer) and ISCC as the leading certification scheme in the biodiesel market could have an influence on this, leaving tight supplies in northwest Europe and causing thus the persistence of premiums (Van Dam et al, 2012 p. 62). Moreover, non-certified biodiesel can still be marketed in EU countries which did not yet transpose the RED, as it is the case in many countries in Eastern Europe.

A common statement among interviewees is the belief that certification will cover most of the biofuels market in the long run. According to the respondents, producers who do not obtain certification might be forced to sell at a discount or be limited to local markets. Furthermore, the initial idea that sustainability certification would be rewarded with price-premiums for certified biofuels and serve as an attractor for other developing countries to reap benefits in the EU market, is apparently unfounded by the data (Walter and Segerstedt, 2012). 
The absence of large sustainability premiums may not be a problem after all. If certification is incorporated in production costs, prices can then converge and certified biofuels can become the new normal practice. The problem then lies in the capacity which different producers have to adapt to certification.

Van Dam et al (2012) found that required auditing days and indirect costs of certification are highest at the start of the supply chain (e.g. farmers). For developed country producers (and advanced developing countries, such as Brazil and Argentina), while adaptation might be costly, producers in these regions are equipped to strategize and deal with certification trends and their consequences. On the other hand, farmers based in lower-income developing countries can have problems to obtain the financing and technical capacities required by the certification process, thus reducing market access and weakening the role of biofuels as a tool for development.

In 2012, the European Commission proposed changes to the EU biofuel policy, in order to address potential negative impacts of biofuels on food prices, as well as Indirect Land Use Change (ILUC) effects brought by their increased usage (Pacini and Strapasson, 2012). The core proposal was to limit first-generation (food-based) biofuels to a maximum of 5\% of the overall goal of $10 \%$ renewables in EU transport by 2020 (European Commission, 2012). This new proposal raised the perception that the two different approaches for sustainability (in the EU and in the US) are heading towards some level of convergence. In other words, a cap on $1^{\text {st }}$ generation biofuels would echo the US strategy of splitting the domestic market into a quota for $1^{\text {st }}$ gen and another for advanced biofuels (cellulosic and high-performing sugarcane ethanol). While this latest proposal in the EU seeks to avoid putting pressure on food prices, as 
well as fostering technological development, it nevertheless constrains markets for producers who invested in sustainability certification for $1^{\text {st }}$ generation crops.

\section{Conclusion}

The introduction of sustainability regulations as a de-facto precondition to market access has brought new costs to the biofuels industry. Beyond mere impacts on private-sector strategies and investment decisions, such regulations have created new aspects to be considered when biofuels are examined as an alternative energy policy option to stimulate socio-economic progress in developing countries. While sustainability certification became a tool which can open doors to new markets, the price for the key to this door can be problematic for producers in less favored regions.

Producers incurring in costs related to compliance with sustainability rules were once thought to be rewarded with price-premiums for certified products. This attracted the interest of developing countries seeking export opportunities towards the European Union. Price-premiums for certified biofuels, however, have been small and some disappeared completely as markets forces adjusted in 2012. Producers are now in a market where new rules dictate how operations should take place and certified sustainable biofuels become the new norm. As adaptation costs tend to be highest for the early stages of the supply chains, producers in low-income developing countries may lack the technical capacity and access to finance instruments to be part of this growing market.

High domestic demand for ethanol in traditional biofuel exporters like Brazil, limited surplus and unchanged import tariffs in the EU, compounded by the lack of noticeable price premiums for sustainable biofuels has resulted in a decrease in developing 
country participation in the EU biofuels market. Conversely, limited investments in the sector took their toll, as a consequence of the global economic crisis.

Sustainability certification appears to be evolving in a way to spread risks, with market agents seeking certification schemes which provide credentials which allow multiple products to access different markets. Producers are on a trend to make "better" biofuels, mostly to secure market access, and not because of premiums as shown by the data. This signals the importance of technical support and efficient private investment in order to aid developing countries not to lag behind in this market, which now operates under increasing levels of regulation. Smallholders and small producers in developing countries need financial and technical support to meet sustainability requirements and remain competitive in the rapidly evolving biofuels industry.

This paper benefited from the discussions which took place in Rio+20, especially on the UNCTAD side-event "No one size fits all: Exploring new sustainable and socially inclusive biofuels options" held at the Brazilian Military Institute of Engineering on June $19^{\text {th }}, 2012$. The authors would like to express their gratitude to UNCTAD, the Low-Carbon Economy Center of FEARP-USP and Platts for providing data used in the development of this note. Special thanks to contributors Guilherme Kfouri (Platts), Rob Vierhout (ePure), Kenneth Light (Raízen Trading), Martin Junginger (Ultrecht University), Chun Sheng Goh (Ultrecht University), Semida Silveira (Royal Institute of Technology), Francis X. Johnson (Stockholm Environment Institute) and Helga Vanthournout (McKinsey \& Co.). All statements shall be attributed to the authors alone, and do not necessarily represent the views of their institutions. 


\section{References}

Afionis, Stavros., Stringer, Lindsay C. (2012) European Union leadership in biofuels regulation: Europe as a normative power? Journal of Cleaner Production 32, pp 114-123.

Batista, Edgard Antunes Dias (2012) After all, is ethanol positive or negative? U FORES publication.

Bonsucro (2011) Better Sugarcane Initiative. Available at: http://www.bonsucro.com/

Börjesson, Pål., Ericsson, Karin., Di Lucia, Lorenzo., Nilsson, Lars J., Åhman, Max. (2009) Sustainable vehicle fuels - do they exist? Available at: http://lup.lub.lu.se/record/1360645/file/1366749.pdf

BP (2012) Interview with biofuel trader.

Cavalcanti, Marcelo., Szklo, Alexandre., Machado, Giovani. (2011) Do ethanol prices in Brazil follow Brent price and international gasoline price parity? Renewable Energy 43, pp 423-433.

CARB (2009) Proposed Regulation to Implement the Low Carbon Fuel Standard Volume I Staff Report: Initial Statement of Reasons. California Environmental Protection Agency, Air Resources Board. Release Date: March 5, 2009.

CEPEA/Esalq (2013) Ethanol price statistics. Available at: http://www.cepea.esalq.usp.br/

CIFOR (2012) Transformations in EU biofuels markets under the Renewable Energy Directive and the implications for land use, trade and forests. CIFOR Occasional Paper 78. Available at: http://www.cifor.org/publications/pdf_files/OccPapers/OP78.pdf

Crago, Christine L., Khanna, Madhu., Barton, Jason., Giuliani, Eduardo., Amaral, Weber. (2010) Competitiveness of Brazilian sugarcane ethanol compared to US Corn Ethanol. Available at SSRN: http://ssrn.com/abstract=1622922 or http://dx.doi.org/10.2139/ssrn.1622922

De Gorter, Harry., Just, David R. (2009) The Economics of a Blend Mandate for Biofuels. American Journal of Agricultural Economics, Vol. 91, Issue 3 pp 738 750.

De Wit, Marc., Junginger, Martin., Lensink, Sander., Londo, Marc., Faaij, Andre. (2010) Competition between biofuels: Modeling technological learning and cost reductions over time. Biomass and Bioenergy 34, Issue 2. pp 203-217.

ECN (2011) Renewable Energy Projections as Published in the National Renewable Energy Action Plans of the European Member States. Energy Research Centre of the Netherlands. Available at: http://www.fjvu.dk/sites/default/files/renewable_energy_projections_as_published _in_the_national_renewable_energy_action_plans_of_the_european_member_state s.pdf

EPA (2010) Renewable Fuel Standard Program (RFS2), Regulatory Impact Analysis. Assessment and Standards Division, Office of Transport and Air Quality U.S. Environmental Protection Agency. EPA-420-R-10-006, February 2010.

EurObserv'ER (2012) Biofuels Barometer 2012. Available at: http://www.eurobserver.org/pdf/baro212.pdf

European Commission (2009) Directive 2009/28/EC of the European Parliament and of the council on the promotion of the use of energy from renewable sources and amending and subsequently repealing Directives 2001/77/EC and 2003/30/EC. 
European Commission (2012) Proposal for a directive amending Directive 98/70/EC relating to the quality of petrol and diesel fuels and amending Directive 2009/28/EC on the promotion of the use of energy from renewable sources. Available http://ec.europa.eu/energy/renewables/biofuels/doc/biofuels/com_2012_0595_en.p $\underline{\mathrm{df}}$

Goldemberg, Jose., Teixeira Coelho, Suani., Nastari, Plinio Mario., Lucon, Oswaldo. (2004) Ethanol learning curve - the Brazilian experience. Biomass and Bioenergy vol 26, Issue 3, pp 301-304.

Hettinga, W.G., Junginger, H.M., Dekker, S.C. Hoogwijk, M. McAloon, A.J., Hicks, K.B. (2009) Understanding the reductions in US corn ethanol production costs: An experience curve approach. Energy Policy 37, Issue 1, pp 190-203.

Kutas, Geraldine. Lindberg, Carina. Steenblick, Ronald. (2007) Biofuels - At what cost? Government support for ethanol and biodiesel in the European Union.

Mathews, John A. (2008) Towards a sustainably certifiable futures contract for biofuels. Energy Policy 36, issue 5. pp 1577-1583.

Pacini, Henrique., Assunção, Lucas. (2011) Sustainable biofuels in the EU: the costs of certification and impacts on new producers. Biofuels vol. 2, Issue 6. pp 595-598.

Pacini, Henrique., Strapasson, Alexandre (2012) Innovation subject to sustainability: the European policy on biofuels and its effects on innovation in the Brazilian bioethanol industry. Journal for Contemporary European Research, Vol 8, Issue 3. pp 368-397.

Pimentel, David. Patzek, Tad W. (2005) Ethanol production using corn, switchgrass and wood; Biodiesel production using soybean and sunflower. Natural Resources Research, Vol. 14 N. 1.

Rathmann, Regis., Szlo, ALexandre., Schaeffer, Roberto. (2012) Targets and results of the Brazilian Biodiesel Incentive Program - Has it reached the Promised Land? Applied Energy 97, pp 91-100.

REN21 (2012) Renewable Global Status Report 2012. Renewable Energy Policy Network for the $21^{\text {st }}$ Century. Available at: http://www.ren21.net

Rosillo-Calle, Frank., Johnson, Francis. (2011) Food vs. Fuel. An informed introduction to Biofuels. ZED books

RSB (2010) Roundtable on Sustainable Biofuels: Institutional Terms of Reference

RTRS (2011) Soy Amount Estimation Methodology for RTRS Certification. Roundtable on Responsible Soy Association

Schlegel, Stephanie., Kaphengst, Timo. (2007) European Union Policy on Bioenergy and the role of Sustainability Criteria and Certification Systems. Journal of Agricultural \& Food Industrial Organization. Available at: http://ecologic.eu/duke/download/JAIFO_bioenergy.pdf

Serra, Teresa., Zilberman, David., Gil, Jose M., Goodwin, Barry K. (2010) Price Transmission in the US Ethanol Market. Chapter 5 in Handbook of Bioenergy Economics and Policy. Springer Verlag.

UNCTAD (2008a) Making Certification Work for Sustainable Development: The Case of Biofuels.

UNCTAD (2008b) Biofuel production technologies: status, prospects and implications for trade and development.

UNCTAD (2009) The Biofuels Market: Current Situation and Alternative Scenarios. pp.15-28.

UNICADATA (2013) Ethanol production and trade statistics. Available at: http://www.unicadata.com.br/ 
Van Dam, Jinke., Ugarte, Sergio., van Iersel, Sjors. (2012) Selecting a biomass certification system - a benchmark on level of assurance, costs and benefits.

Van Dam, Jinke; Junginger, Martin. (2011) Striving to further harmonization of sustainability criteria for bioenergy in Europe: Recommendations from a stakeholder questionnaire. Energy Policy 39, issue 7. Pp 4051-4066.

Van Dam, Junke., Junginger, M. Faaij, A.P.C. (2010) From the global efforts on certification of bioenergy towards an integrated approach based on sustainable land use planning. Renewable and Sustainable Energy Reviews 14, pp 2445-2472.

Walter, Arnaldo., Segerstedt, Anna. (2012) International Trade of Biofuels: Current Trends and the Potential Role of Africa. Bioenergy for Sustainable Development in Africa, Part 2. pp 147-162.

Zhang, Zibin., Qiu, Cheng., Wetzstein, Michael. (2010) Blend-wall economics: Relaxing US ethanol regulations can lead to increased use of fossil fuels. Energy Policy 38, Issue 7. pp 3426-3430. 